\title{
JOURNAL.RU
}

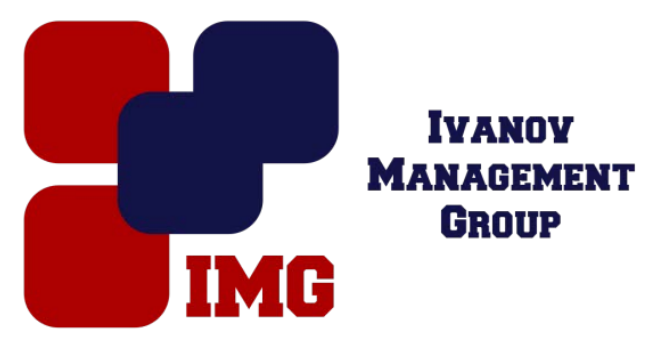

Жаркова К.С., Абрамова Д.Д., Григорьева Н.С. Самарский государственный университет путей сообщения

Самара, Россия

doi: 10.18411/lj-25-12-2016-3-09

idsp 000001:lj-25-12-2016-3-09

\section{Статистический очерк региональных факторов экономического развития на примере Самарской области}

\section{Аннотация}

В данной статье рассмотрены факторы, влияющие на современное состояние и уровень становления регионов, определяющие историю становления страны и существующие тенденции ее развития.

Ключевые слова: региональная экономика, факторы, статистика, анализ, Самарская область

В условиях глобализации национальной экономики необходимо интенсивно работать над поддержанием собственной конкурентоспособности. Опасности становления имеют все шансы формироваться как внутри державы, так и приходить извне. Это событие выдвигает на главное по значимости место проблему поиска новой политики экономического становления.

В минувшие годы выросла независимость регионов, которые несли большую ответственность за итоги регионально-экономического развития. Социально-экономическое становление региона - это центральная функция органов власти региона, которая становится важной во время структурных изменений. Анализ и прогнозирование социально-экономического развития является отправной точкой мероприятий, сосредоточенных на управлении региональным развитием. На основе аргументированного прогноза определяются цели социально-экономического развития региона, устанавливаются программные мероприятия и ценности в развитии регионального хозяйственного комплекса. Управление развитием региона может осуществляться с помощью обширного спектра определенных действий, посредством которых районная администрация мотивирует развитие экономики региона, создает новые рабочие места, увеличивает налоговую базу, расширяет возможности для тех видов экономической активности, в которых заинтересовано районное общество. 
На сегодняшний день ВВП является основным фактором, описывающим экономическое положение государств. Его уровень считается базой формирования бюджета государства; его динамика показывает качество принятых управленческих решений, направленных на экономический рост.

Таблица 1.

Группь факторов уровня развития региональной экономики

\begin{tabular}{|c|c|c|}
\hline \multicolumn{3}{|c|}{ Факторы } \\
\hline Экономические & Социальные & Технологические \\
\hline 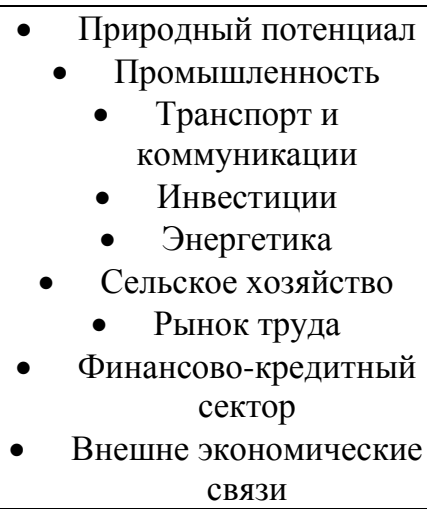 & $\begin{array}{c}\text { • Демография и миграция } \\
\text { • Образование } \\
\text { • } \text { Здравоохранение } \\
\text { Уровень безработицы } \\
\text { • } \quad \text { Благосостояние } \\
\text { Платежеспособность } \\
\text { населения } \\
\text { • Экология }\end{array}$ & $\begin{array}{c} \\
\text { • } \\
\text { Инновационная } \\
\text { Рельность предприятий } \\
\text { Развитие науки технологий } \\
\text { и инноваций }\end{array}$ \\
\hline
\end{tabular}

В условиях развития рыночных взаимоотношений появляется объективная потребность в изучении специфики воспроизводственных действий определенного региона способом исследования концепции экономической безопасности и реализации основ устойчивого становления. На воспроизводственный процесс воздействуют объективные и субъективные причины.

К объективным факторам можно отнести: уровень становления региона, структуру хозяйства, природно-экономическое положение, введение новых форм хозяйствования и так далее. Так же важны и субъективные факторы такие как: политика властей всех уровней по отношению к региону, предпринимательская активность населения, инвестиционная привлекательность, поддержка или противодействие к реформированию. Можно отметить, что направленность действия субъективных факторов в значимой мере определяет скорость и направленность развития объективных факторов. Одной из важных специфических отличительных черт региона, оказывающих большое воздействие на структуру экономики, является природно-ресурсный потенциал. По мнению научных работников РБ, несмотря на колоссальное обилие ресурсов, только маленькая часть из них может быть эффективно применена в промышленных целях, так как месторождения являются с малыми запасами и ограничением научно-технической и автотранспортной доступность. В решении этих проблем невозможно обойтись без статистических данных. В наше время статистика должна обеспечивать органы муниципального управления всех уровней, коммерческие структуры и общественность объективной, значимой и абсолютной информацией, связанной с вопросами о социально-экономическом развитии регионов и отраслей экономики. 
Статистическая информация используется для исследования экономической и социальной политики, формирования проектов бюджетов, получения прогнозов становления. Теперь мы можем сделать вывод, что статистика играет важную роль в формировании информационной инфраструктуры экономики, социальной сферы и общества в целом.

Чтобы процесс социально-экономического становления региона проходил удачно и приводил к нужному итогу, он должен быть контролируемым. Поэтому важное значение для социально-экономического становления региона имеет организационный момент (территориальное управление).

Для удачного решения регионом социально-экономических проблем потребуется активное воздействие организационного фактора. Территориальное и единое управление делает следующие главные функции: планирование, оперативное регулирование, координация, учет и контроль. В роли организующего инструмента управления выступает административнотерриториальное деление государства, которое играет весомую роль в регулировке хозяйственного становления, в осуществлении правоохранительной, оборонной и прочих функций страны. Административнотерриториальная система способствует комплексному развитию регионов, координированию и контролю работы находящихся в них компаний и учреждений, организации территориального планирования и управления.

Абсолютно любой регион не в силах иметь преимущество по всем факторам. У каждого района есть свой собственный набор преимуществ, делающий его как экономически, так и общественно развитым. Для того чтобы сберечь и увеличить уровень социально-экономического становления региона, нужно каждый раз улучшать группу факторов, оказывающих воздействие на данное становление.

Таким образом, на региональное становление влияет тот или иной набор факторов. Именно факторы регионального становления используются для разъяснения, моделирования и оценки социально-экономической ситуации в регионе. 


\section{Литература}

1. Первов П.А., Звездин В.В. Разработка программы динамического ценообразования для пассажирского железнодорожного транспорта // Вестник СамГУПС. 2015. № 1 (27). - С. 28-32.

2. Первов П.А., Звездин В.В. Формирование программного комплекса для расчета влияния применения аутсорсинга на итоговые финансовые показатели предприятий железнодорожного транспорта // Наука и образование транспорту. 2013. Т. 1. № 1. С. 147-150.

3. Карышев М.Ю. Проблемы и перспективы развития статистики сферы информационно-коммуникационных технологий в направлении международных стандартов качества // Вопросы статистики, 2011. № 11. С. 27-31

4. Дворникова Ю.В., Гизатуллина О.М. Формирование адаптивной системы оценки финансовой устойчивости предприятия // Наука и образование транспорту. 2014. № 1. С. 124-126.

5. Дворникова Ю.В. Экономическая оценка инновационной деятельности на российских железных дорогах. Диссертация на соискание ученой степени кандидата экономических наук / Самара, 2006

6. Синяева Л.П., Герасимова Е.А., Додорина И.В. Опыт оценки структуры потребностей сотрудников для формирования системы их мотивации // Вестник СамГУПС. 2015. № 3 (29). - С. 142-147. 